\title{
БУЛЦУУНЫ БАКТЕРИЙН ӨСГӨВРYYД LUPINUS ALBUS L-ИЙН ДЕГА СОРТЫН УРГАМЛЫН ӨСӨЛТӨНД ҮЗУУЛСЭН НӨЛӨӨ
}

\author{
Ч. Зулиэиэг' \\ 1 Ерөнхий болон сорильн биологийн хүрээлэнгийн Микробын нийлэгжлийн лаборатори, ШУА, Монгол улс \\ 2 Российский государственный аграрный университет-МСХА имени К.А.Тимирязева \\ 3 Всероссийский научно-исследовательский институт кормов имени В.Р. Вильямса \\ Цахим шуудан: zulaa178@mail.ru
}

\section{Хураангуй}

Булиууны бактери нь Lupinus albus L (Цагаан шомлой) бууриагт ургамльн үндсэнд симбиоз ҮҮсгэн агаарын азотыг шингээж тэжээлийн бодисоор хангаж өгдөг. Гэрийн тэжсээвэр амьтдын уурагт тэжээл Цагаан шошлойны Дега, Дельта, Деснянский сортоос ялгасан булиууны бактерийн ДГА 3-2, ДЛТ 3-2, ДСН1-1 болон 363 а тест өсгөврөөр Дега сортын ургамльн үрийг халдварлуулан тариалж идэвхтэй симбиоз үүсгэлтийг биометрийн болон биохимийн үзүүлэлтээр хэмжив.

Цагаан шошлойны үрийг булиууны бактерийн ДСН1-1 өсгөврөөр халдварлуулан тариалахад ногоон масс 28.6\%, үрийн эслэг 97,7\%, ДЛТ 3-2 өсгөврөөр халдварлуулахад ногоон массын тослог 47,7\%, эслэг 19,7\%, ДГА 3-2 өсгөврөөр халдварлуулахад ногоон массын тослог 51,8\%-иар нэмэгдсэн. Дега сортын ургамалд булиууны бактерийн ДСН1-1, ДЛТ 3-2 өсгөвөр идэвхтэй симбиоз Үүсгээс байна.

Түлхүур Үг: Цагаан шошлой, булиууны бактери, өсгөвөрлөлт, ургамльн өсөлт

\section{ОРШИЛ}

Rhizobium - буурцагт ургамлын үндсэнд симбиоз үүсгэн оршдог, генетикийн хувьд олон бүлэгт хамаарах Грам сөрөг бичил биетэн юм. Эдгээр нь агаарын азотыг шингээн ургамлыг тэжээлийн бодисоор хангаж, хөрсийг азотоор баяжуулахаас гадна буурцагт ургамлыг хортон шавьж, өвчин үүсгэгчээс хамгаалах, орчны таагүй нөхцөлд дасан зохицох чадварт эерэг нөлөө ҮзҮҮлдэг. Буурцагтны булцууны бактерийн симбиоз үүсгэлт гадаад орчны хүчин зүйлс болох температур, чийг, хөрсний $\mathrm{pH}$, давсны концентрациас ихээхэн хамаардаг $[8,10,11]$.

Lupinus albus L буюу Цагаан шошлойны үр болон ногоон масссыг гэрийн тэжээвэр тахиа, гахайнд уурагт тэжээл болгон дэлхийн олон оронд өргөн хэрэглэж байна.
Цагаан шошлойн үрийн найрлагад 37-42\% уураг, $10-12 \%$ тос, $7 \%$ эслэг агуулдаг, үрийн шинж чанараар шар буурцагтай ойролцоо боловч хөрс, цаг уурын нөхцөлд илүү мэдрэг. 1960-аад оноос эхлэн Гатаулина болон бусад эрдэмтэд Lupinus albus $L$ ийн ургалтын хугацааг богиносгох, өвчин үүсгэгчид тэсвэртэй болгох (фузариоз болон антракноз), ургацыг нэмэгдүүлэх, үрийн чанарыг сайжруулах чиглэлээр селекцийн ажил явуулсны дүнд олон сорт гарган авсан $[4,5]$.

ОХУ-д 2004 онд бүртгэгдсэн Дега сортыг тэжээлийн эх үүсвэр болгон хамгийн өргөн хэрэглэж байна. Дега сортын вегетацийн хугацаа 115-130 хоног, өвчин Үүсгэгч мөөгөнцөрт тэсвэртэй, үрийн найрлагадаа $8-10 \%$ тос, $37-38 \%$ уураг, ногоон массдаа 
$18-20 \%$ хуурай бодис агуулдаг $[3,12]$.

Цагаан шошлой нь булцууны бактеритай симбиоз үүсгэдэг учир үрийг урьдчилан булцууны бактерийн суспензээр халдварлуулан тариалах аргыг ашиглан ургацын хэмжээ, чанарыг нэмэгдүүлэхээс гадна, тухайн сортод тохирсон өсгөвөр гарган авах боломжтой юм $[9,11]$.

\section{СУДАЛГААНЫ МАТЕРИАЛ, АРГА ЗУЙ}

Судалгаанд К.А.Тимирязевын нэрэмжит ХАA-н академийн МикробиологиИммунологийн тэнхимийн өсгөврийн сангийн Lupinus albus L-ийн Дега, Дельта, Деснянский сортын булцуунаас ялгасан (ДГА 3-2, ДЛТ 3-2, ДСН1-1) бактерийн 3 өсгөвөр, 363а тест өсгөврийг (ОХУийн Санкт-Петербург хотын ХАA микробиологийн хүрээлэнгийн өсгөврийн сан) сонгон авсан. Дээрхи өсгөврийн морфологи, физиологи-биохимийн шинж чанар тодорхойлогдсон [1].

К.А.Тимирязевын нэрэмжит ХАА-ийн академийн туршилтын талбайд Lupinus

\section{СУДАЛГААНЫ ҮР ДУН}

Lupinus albus L-ийн Дега, Дельта, Деснянский сортоос ялгасан булцууны бактерийн ДГА 3-2, ДЛТ 3-2, ДСН1-1 болон 363а тест өсгөврөөр Дега сортын ургамлын үрийг халдварлуулан тариалж
Селекцийн дүнд гарган авсан Цагаан шошлойны булцуунд симбиоз Үүсгэн агаарын азот шингээгч бактерийг ашиглан микробиологийн аргаар Дега сортын ургацыг нэмэгдүүлэх судалгаa анхлан хийж байгаад бидний ажлын шинэлэг тал оршино.

albus L-uйн Дега сортын үрийг булцууны бактерийн $10^{6}-10^{8}$ эс/мл-ийн суспензээр халдварлуулан тариалж, биометрийн хэмжилтийг цэцэглэлт болон буурцаг үүсгэлтийн эхэн үед 12 давталттайгаар нийтлэг арга зүйн дагуу хийж, хяналтаар эсийн суспензээр халдварлуулаагүй үрийг авсан $[2,7,10]$.

Үрийн болон хуурай ногоон массын химийн найрлагыг биохимийн нийтлэг хэрэглэгддэг арга зүйгээр тодорхойлов [6].

Yp дүнгийн боловсруулалтанд SPSS 16.0 статистикийн программ ашигласан.

идэвхтэй симбиоз үүсгэлтийг биометрийн болон биохимийн үзүүлэлтээр хэмжив.

Биометрийн хэмжилтийг цэцэглэлт болон булцуу үүсгэлтийн эхэн үед хийсэн үр дүнг Хүснэгт 1-д үзүүлэв.

Хүснэгт 1. Булиууны бактерийн өсгөврУУд Дега сортын ургамлын өсөлтөнд нөлөөлсөн дүн

\begin{tabular}{|c|c|c|c|c|c|}
\hline \multirow{2}{*}{ Үзуүлэлт } & \multicolumn{5}{|c|}{ Хувилбар } \\
\cline { 1 - 2 } & Хяналт & $363 \mathrm{a} /$ тест/ & дЛТ 3-2 & дСН1-1 & ДГА3-2 \\
Ургамлын жин, г & $73.1 \pm 15.1$ & $74.8 \pm 9.0$ & $74.9 \pm 5.9$ & $\mathbf{9 4 . 0 \pm 7 . 8}$ & $79.7 \pm 18.4$ \\
Ургамлын өндөр, см & $57.7 \pm 3.2$ & $60.5 \pm 3.7$ & $57.7 \pm 3.2$ & $57.6 \pm 2.5$ & $59.4 \pm 7.9$ \\
Үндэсний жин, г & $5.7 \pm 1.4$ & $3.9 \pm 1.3$ & $4.9 \pm 0.6$ & $6.3 \pm 0.7$ & $7 \pm 1.8$ \\
Булцууны тоо, ш & $57.1 \pm 12.9$ & $57.0 \pm 7.2$ & $43.3 \pm 2.4$ & $50.8 \pm 5.5$ & $49.3 \pm 4$ \\
Булцууны жин, г & $0.27 \pm 0.05$ & $0.64 \pm 0.1$ & $\mathbf{2 . 9} \pm \mathbf{0 . 1}$ & $\mathbf{2 . 7 \pm 0 . 1}$ & $0.53 \pm 0.2$ \\
Леггемоглобин мг/г & 2,66 & 2,76 & 2.75 & 2.56 & 2,35 \\
\hline
\end{tabular}

Булцууны бактерийн буурцагт ургамалд ашигтай симбиоз үүсгэн өсөлтөнд нөлөөлж байгаa эсэхийг ургамлын жингийн нэмэгдэлт, булцууны хэмжээ, леггемоглобины агууламж зэрэг олон шинжүүдээр тодорхойлох боломжтой. 
Хүснэгт 1.ээс харахад туршилтын ДСН1-1 өсгөврөөр халдварлуулсан ургамлын жин хяналтийн хувилбар (халдварлуулаагүй) болон $363 \mathrm{a}$ тест өсгөврөөр халдварлуулсанаaс 28,6\%иар илүY $(\mathrm{p}>0.05)$ байгаа бол бусад 2 хувилбарт ойролцоо байв. Навчны болон булцууны тоо, ургамлын өндөрт нөлөө бага үзүүлсэн. Ургамлын газрын доод хэсэгт өсөлт өөрчлөлт нилээд ажиглагдав. ДЛТ 3-2, ДСН1-1, ДГА 3-2 өсгөврөөр тус бүр халдварлуулсан хувилбарт цөөн тоотой, том хэмжээтэй, улаан ягаан өнгөтэй булцуу үүссэн бол хяналтын хувилбаруудад олон жижиг булцуу үүссэн.

Булцууны жингээр ДСН1-1, ДЛТ 3-2 өсгөврөөр халдварлуулсан хувилбар хяналтаас $10,0-10,7$ дахин $(\mathrm{p}<0.05)$, тест өсгөврөөс 4,2-4,5 дахин их $(\mathrm{p}<0.05)$, булцууны тоогоор 1,1-1,3 дахин бага, ДГА 3-2 өсгөврөөр халдварлуулсан хувилбар булцууны жин 1,9 дахин их байсан.

Туршилтын 3 хувилбарт булцуун дахь леггемоглобины хэмжээ 2,3-2,75 мг/г байгаа нь хяналт болон 363a- тест өсгөвөртэй ижил байна.

Идэвхтэй симбиоз үүсгэлтийг тодорхойлох бас нэг гол үзүүлэлт нь тэжээлийн ургамлын ногоон масс болон үрийн найрлага дахь уургийн агууламжийн өсөлт юм.

Дега сортын цэцэглэлт болон булцуу үүсгэлтийн эхэн үеийн ногоон массны хуурай дээжинд химийн найрлагийг тодорхойлсон дүнг Хүснэгт 2-д үзүүлэв.

ХУснэгт 2. Булиууны бактерийн өсгөврҮҮд Дега сортын ногоон массын химийн найрлагад үзүҮлсэн дүн (абс.хуурай жин,\%)

\begin{tabular}{|c|c|c|c|c|c|}
\hline \multirow{2}{*}{ Хувилбар } & \multicolumn{5}{|c|}{ Үзуулэлт , \% } \\
\cline { 2 - 6 } & Эслэг & Тослог & Уураг & Уусдаг уураг & Үнслэг \\
\hline Хяналт & 7,56 & 2,16 & 29,06 & 25,53 & 8,68 \\
\hline 363 a & 8,49 & 2,31 & 28,13 & 24,75 & 10,01 \\
\hline ДЛТ 3-2 & 9,05 & 3,19 & 31,63 & 28,03 & 10,15 \\
\hline ДСН1-1 & 8,72 & 2,64 & 31,63 & 28,01 & 10,23 \\
\hline ДГА 3-2 & 8,50 & 3,28 & 31,44 & 27,70 & 9,45 \\
\hline
\end{tabular}

Хүснэгт 2ээс харахад ногоон массын уургийн агууламж судалгааны 3 өсгөврөөр тус тус халдварлуулсан хувилбар хяналт болон 363а тест өсгөвөртэй хувилбараас 8.9$12.3 \%$-иар нэмэгдсэн байна. Тослог, эслэг болон үнслэгийн хэмжээг ногоон массд 12,319,7\%-иар нэмэгдүүлж байна.

Ургамлын буурцаг, иш, үндэс химийн найрлагаар хяналт болон хувилбаруудаас ялгаагүй байв.

Дега сортын үрийг махны чиглэлийн тахианд уурагт тэжээлийн эх үүсвэрээр маш өргөн хэрэглэдэг бөгөөд 2 дахь шар буурцаг гэж нэрлэдэг $[3,13]$. Үрийн химийн найрлагыг тодорхойлсон дүнг Хүснэгт Зэд үзүүлэв.

Хүснэгт 3. Булиууны бактерийн өсгөврүҮд Дега сортылн үрийн химийн найрлагад үзҮүлсэн дүн (абс.хуурай жин,\%)

\begin{tabular}{|c|c|c|c|c|c|}
\hline \multirow{2}{*}{ Хувилбар } & \multicolumn{5}{|c|}{ Биохимийн найрлага, \% } \\
\cline { 2 - 6 } & Эслэг & Тослог & Уураг & Уусдаг уураг & Үнслэг \\
\hline Хяналт & 5,14 & 10,87 & 42,00 & 37,44 & 5,24 \\
\hline 363а & 4,91 & 10,88 & 41,56 & 37,02 & 4,98 \\
\hline ДЛТ 3-2 & 7,94 & 11,45 & 37,19 & 32,91 & 4,72 \\
\hline ДСН 1-1 & 10,16 & 11,23 & 36,31 & 32,22 & 4,81 \\
\hline ДГА 3-2 & 4,38 & 11,46 & 41,13 & 36,55 & 5,18 \\
\hline
\end{tabular}


Судалгаанд авсан ДЛТ 3-2, ДСН1-1 халдварлуулсан хувилбарт үрийн уургийн агууламж хяналт болон 363а тест өсгөвөртэй хувилбараас буурсан боловч эслэгийн хэмжээ 1,5-2,1 дахин нэмэгдсэн. Үрийн найрлага дахь тослогийн хэмжээ 5\% хүртэл хэмжээгээр нэмэгдэж, үнслэгийн хэмжээнд маш бага нөлөө үзүүлсэн.

\section{ДҮГНЭЛТ}

Lupinus albus $L$ буюу цагаан шошлойн үрийг булцууны бактерийн ДСН1-1 өсгөврөөр халдварлуулан тариалахад ногоон масс $28.6 \%$, үрийн эслэг 97,7\%, ДЛТ 3-2 өсгөврөөр халдварлуулахад ногоон массын тослог 47,7\%, эслэг 19,7\% ДГА
3-2 өсгөврөөр халдварлуулахад ногоон массын тослог 51,8\%-иар нэмэгдсэн. Дега сортын ургамалд булцууны бактерийн ДСН1-1, ДЛТ 3-2 өсгөвөр ургацын чанарыг сайжруулж байна.

\section{Талархал}

ШУА-ийн Ерөнхий болон Сорилын Биологийн Хүрээлэнд, ОХУ-ийн Тимирязевийн нэрэмжит ХАА академийн микробиологи-иммунологийн тэнхим, ургамал хамгаалалын тэнхимийн хамт олонд судалгаа хийх боломж олгосонд, тус сургуулийн аспирант Н.Саруул, Н.Цэгмид, Д.Уранбайгаль, оюутан А.Хосзаяа нарт судалгааны явцад тусалсанд гүн талархал илэрхийлэе.

\section{Ашигласан бүтээлийн жагсаалт}

1. Чадраабал Зулиэиэг, О.В.Селичкая, А.С. Цыгуткин, Г.В. Степанова Влияние новых штаммов клубеньковых бактерий на рост и развитие белого люпина сорта Детер 1 // Достижения науки и техники АПК. 2015. Т. 29. № 11. С 78-80.

2. Чадраабал Зулиэцэг, О.В.Селичкая, А.С. Цыгуткин, Г.В. Степанова Морфофизиологические характеристики природных изолятов клубеньковых бактерий люпина белого разныхх сортов -Эрдэм шинжилгээний бүтээл №31, Ерөнхий ба сорилын биологийн хүрээлэн. 2015. x-143-148.

3. Гатаулина Г.Г., Медведева Н.В. Бельй люпин перспективная кормовая культура // Достижения науки и техники АПК. 2008. №10. С. 49-51.

4. Гатаулина Г.Г., Сорта белого люпина селекции ФГОУ ВПО РГАУ-МСХА имени К.А.Тимирязева: методические рекомендачии/ Гатаулина Г.Г., Медведева Н.В., Цыгуткин А.С.М.:Изд-во РГАУ-МСХА, 2010. 24 с.

5. Гатаулина Г.Г. Рост, развитие, урожайность и кормовая изенность сортов белого люпина (Lupinus albus L.) селекции РГАУ-МСХА имени К.А.Тимирязева/Гатаулина Г.Г., Медведева Н.В., Штеле А.Л., Цыгуткин А.С.//Известия Тимирязевской сельскохозяйственной академии. 2013.№6. С.12-30.

6. Косолапов В.М, Чуйков В.А, Худякова Х.К, Косолапова В.Г Физико-химические методы анализа кормов - М.: Издательский дом Типография Россельхозакадемии, 2014. - С. $32-95$

7. Посыпанов Г.С. Методы изучения биологической фиксаиии азота воздуха. М.: Агропромиздат, 1991. $300 \mathrm{c}$.

8. Симарова Б.В Генетические основы селекции клубеньковых бактерий. Ленинград: Агропромиздат, 1990. С. 5-18.

9. Степанова Г.В., Золотарев В.Н., Прудникова С.В. Повышение адаптивной способности вики посевной и лючерны изменчивой путем конструирования эффективных симбиотических сортомикробных систем // Повышение устойчивости 
производства сельскохозяйственных культур в современных условиях. - Орел: ПФ «Картуш», 2008. - C. 410-419.

10. Румянцева М.Л., Симаров Б.В., Онищук О.П. и др. Биологическое разнообразие клубеньковых бактерий экосистемах и агроченозах. Теоретические основы и методы/ Под ред МЛ.Румяниевой, Б.В.Симарова. СПб, ВНИИСХМ, 2011.104 c.

11. Тихонович И.А., Проворов Н.А. Симбиозы растений и микроорганизмов: молекулярная генетика агросистем будущего. СПб.: Изд-во С-Петерб.ун-та, 2009.

12. Цыгуткин А.С. Демонстрационный опыт в системе методов опытного дела // Агрофизика. - 2012. - №2. - C. 37-42.

13. Штеле А.Л Кормовая иенность белого люпина для высокопродуктивной птииы . / За бельм люпином будущее Механизация уборки и переработки Лучший корм для птицьљ/. Бельий люпин- Изд-во Москва, 2014. №1,с 15-20. 


\title{
INFLUENCE OF RHIZOBIA STRAINS ON GROWTH OF A DEGA VARIETY OF LUPINUS ALBUS L
}

\author{
Zultsetseg Chadraabal ${ }^{1}$, O.V. Selitskaya ${ }^{2}$, A.S.Tsygutkin ${ }^{2}$, G.V.Stepanova ${ }^{3}$, D.L.Evstigneev ${ }^{2}$ \\ ${ }^{1}$ Laboratory of Microbial synthesis, Institute of genetal and experimental biology, MAS \\ ${ }^{2}$ Russian State Agrarian University - Moscow Timiryazev Agricultural Academy \\ ${ }^{3}$ Federal State Budget Scientific Organization "All-Russian Williams Fodder Research Institute \\ E-mail: zulaa178@mail.ru
}

\begin{abstract}
Rhizobium forms a symbiotic relationship with roots of legume plant Lupinus albus L (white lupine). They absorb atmospheric nitrogen and then provide organic compounds to the plant. Seeds of a Dega variety Lupinus albus L plant were inoculated with rhizobia DGA3-2, DSN1-1, DLT 3-2 strains isolated from variaties Dega, Desnyansky, Delita variety-high protein feeds for domestic animals. Rhizobium-legume symbioses were examined by biometric and biochemical analyses.

When seeds of a Dega variety Lupinus albus $L$ plant were inoculated with DSN1-1 rhizobium strain, wet biomass and fiber of seed were $28.6 \%$ and $97.7 \%$, respectively. When the seeds were inoculated with DLT 3-2 strain, lipid and fiber of wet biomass were increased by $47.7 \%$ and $19.7 \%$, respectively. When the seeds were inoculated with DGA 3-2 strain, the lipid of wet biomass was increased by 51.8\%. Rhizobia DSN1-1, DLT 3-2 strains were more effectively forming symbioses with the Dega variety Lupinus albus $L$ plants.
\end{abstract}

Key words: white lupine, nodule bacteria, inoculation, productivity of plants. 